\title{
Tick Infestation and Piroplasm Infection in Barbarine and Queue Fine de 1'Ouest Autochthonous Sheep Breeds in Tunisia, North Africa
}

\author{
Médiha Khamassi Khbou ${ }^{1, *}$, Mariem Rouatbi ${ }^{2}$, Rihab Romdhane ${ }^{2}$, Limam Sassi ${ }^{2}$, Mohamed Jdidi ${ }^{2}$, \\ Aynalem Haile ${ }^{3}$, Mourad Rekik ${ }^{4}$ and Mohamed Gharbi ${ }^{2}$
}

check for updates

Citation: Khamassi Khbou, M.;

Rouatbi, M.; Romdhane, R.; Sassi, L.; Jdidi, M.; Haile, A.; Rekik, M.; Gharbi, M. Tick Infestation and Piroplasm Infection in Barbarine and Queue Fine de l'Ouest Autochthonous Sheep Breeds in Tunisia, North Africa. Animals 2021, 11, 839. https:// doi.org/10.3390/ani11030839

Received: 12 October 2020 Accepted: 23 December 2020 Published: 16 March 2021

Publisher's Note: MDPI stays neutral with regard to jurisdictional clai$\mathrm{ms}$ in published maps and institutional affiliations.

Copyright: () 2021 by the authors. Licensee MDPI, Basel, Switzerland. This article is an open access article distributed under the terms and conditions of the Creative Commons Attribution (CC BY) license (https:// creativecommons.org/licenses/by/ $4.0 /)$.
1 Laboratory of Infectious Animal Diseases, Zoonosis and Sanitary Regulation, Institution of Agricultural Research and Higher Education, National School of Veterinary Medicine of Sidi Thabet, Univ. Manouba, Sidi Thabet 2020, Tunisia

2 Laboratory of Parasitology, Institution of Agricultural Research and Higher Education, National School of Veterinary Medicine of Sidi Thabet, Univ. Manouba, Sidi Thabet 2020, Tunisia; rouatbi.myriam@yahoo.fr (M.R.); rihabromdhaneveto@gmail.com (R.R.); sassilimam@yahoo.fr (L.S.); jdidimohamed79@gmail.com (M.J.); gharbim2000@yahoo.fr (M.G.)

3 International Center for Agricultural Research in the Dry Areas (ICARDA), P.O. Box 5689, Addis Ababa, Ethiopia; a.haile@cgiar.org

4 International Center for Agricultural Research in the Dry Areas (ICARDA), P.O. Box 950764, Amman 11195, Jordan; m.rekik@cgiar.org

* Correspondence: mediha.khamassi@enmv.uma.tn; Tel.: +216-50-549-649

Simple Summary: Ticks and tick-borne pathogens affect the productivity of sheep in Tunisia. Searching for genetically resistant breeds to infestation by ticks may represent an alternative to the overuse of chemical drugs. The aim of this study was to assess if there is any difference in tick infestation among the main sheep breeds in Tunisia. Four hundred and thirty-nine ear-tagged ewes from Barbarine and Queue Fine de l'Ouest (QFO) breeds were examined and sampled each trimester for two years. Ticks were identified to the species level, and piroplasms were detected using Polymerase Chain Reaction (PCR). Queue Fine de L'Ouest ewes were markedly less infested by ticks, and none was infected by piroplasms compared with Barbarine conterparts. The QFO sheep breed could be considered in concrete control strategies, including a breeding program.

Abstract: As ticks and tick-borne pathogens affect the productivity of livestock, searching for genetically resistant breeds to infestation by ticks may represent an alternative to the overuse of chemical drugs. The aim of this study was to assess if there is a difference in tick infestation among the main sheep breeds in Tunisia. The study was carried out between April 2018 and January 2020 in 17 small to middle-sized sheep flocks from 3 regions across Tunisia. Four hundred and thirty-nine ear-tagged ewes from Barbarine $(n=288,65.6 \%)$ and Queue Fine de l'Ouest (QFO) $(n=151,34.4 \%)$ breeds were examined and sampled each trimester. Ticks were identified to the species level, and piroplasms were detected using PCR that targets a common sequence ARNr18S to both Babesia and Theileria genera using catch-all primers. Totally, 707 adult ticks were collected from animals; 91.4\% (646/707) of them were Rhipicephalus sanguineus s.l. Queue Fine de l'Ouest animals were markedly less infested by ticks, and no one of them was infected by piroplasms compared to the Barbarine breed. Indeed, during the first four seasons, 21 animals, all from the Barbarine breed, were detected positive for piroplasms. This is the first study in Tunisia about the low susceptibility of QFO ewes to infestation by ticks and to infection by piroplasms. The QFO sheep breed could be raised preferably at high-risk areas of tick occurrence and could be considered in concrete control strategies, including a breeding program.

Keywords: breed; sheep; resistance; ticks; piroplasms; Tunisia 


\section{Introduction}

Several parasite infections compromise small ruminant health, food security and human health. In Tunisia, sheep face several endoparasites and ectoparasites-when cumulated to bacterial and viral infections and to technically irrational herd management practices-that deeply impede the whole sector development. Ticks and tick-borne pathogens (TBP) (Theileria spp., Babesia spp., Anaplasma spp., Borrelia spp.) affect the productivity of sheep and may cause huge economic losses [1-4]. In addition to the pathogens they transmit, ticks cause skin irritations, dermatitis, bacterial infections and blood spoliation that could lead to chronic anemia [5]. Ticks are conventionally controlled through acaricides application. However, resistance to acaricide is growing and spreading in tick populations, leading to the failure of anti-ticks control programs [6,7]. Moreover, chemical acaricides are toxic to consumers, persons handling animals, treated animals and are persistent in the environment, making such a strategy not complying with the principles of Eco-Health [8]. Searching for genetically resistant breeds of livestock to infestation by ticks may represent an irreversible and sustainable mechanism for the control and an alternative to the overuse of chemical drugs. Although the genetic background is responsible for any inherent resistance mechanism to ticks [9], other factors linked to the animal or its environment such as age, gender, physiological status, behavior, coat characteristics, size, food regimen, as well as climate and environment, could have a role [10]. Resistance to tick infestation was widely investigated in cattle $[11,12]$ and experimental animals such as guinea-pigs $[13,14]$. In cattle, resistance to ticks was shown to be heritable [15], and in South African cattle, heritability for tick resistance assessed by tick counts was estimated between naught and 0.89 [16]. There are limited studies and reports on sheep. In this important livestock species, the genetic resistance was investigated mainly for flies [17] and gastrointestinal nematodes [18]. The heritability of resistance to ticks was estimated to 0.32 to 0.59 in Norwegian sheep [19], and since heritability for tick resistance is moderate [20], such a trait could be included in breeding programs.

The genetic resistance to tick infestation is also immunologically mediated. Both innate and acquired immunity are involved in tick resistance [21]. Wada et al. [22] reported that resistance to tick appears after repeated tick infestations, the fourth infestation in cattle [23] but after a single tick infestation in sheep [24]. The histological examination of tick site attachment, the quantification of circulating $\mathrm{T}$ and B lymphocytes [25], cytokine synthesis [26] and examination of gene expression in the skin [27] were investigated by several authors mainly for tick resistance in cattle, but not in sheep.

Most of the studies on ticks and tick-borne pathogens in Tunisia focused on comparing prevalence according to livestock species, age, geographic areas, but few included variations between breeds. In a study carried out in the district of Siliana (northwest Tunisia), Elati et al. [28] found that 7.3\% (103/284) and 16.7\% (303/362) of Barbarine and Queue Fine de l'Ouest (QFO) surveyed animals, respectively, were infested by ticks. This study provided preliminary investigations into the presence of a difference in the receptivity of sheep to ticks. However, the survey period was relatively short, and it was geographically very restricted. Our study is based on two of the main sheep types in North Africa, Barbarine and QFO. Depicting forms of resistance among these 2 breeds for ticks and pathogens transmitted by ticks may add valuable information in designing breeding schemes. Extending over a period of 2 years and covering the main areas where these 2 breeds prevail in Tunisia, the current study investigated variability among Barbarine and QFO sheep to infestation by ticks and infection by piroplasms (Babesia/Theileria).

\section{Materials and Methods}

\subsection{Study Region and Sampling Design}

This repeated cross-sectional study was carried out from April 2018 to January 2020. A total of 17 small to middle-sized (10 to 50 ewes per flock) and extensively managed sheep flocks were randomly selected from the northeast, the northwest and the southeast regions of Tunisia (Figure 1 and Table 1). 


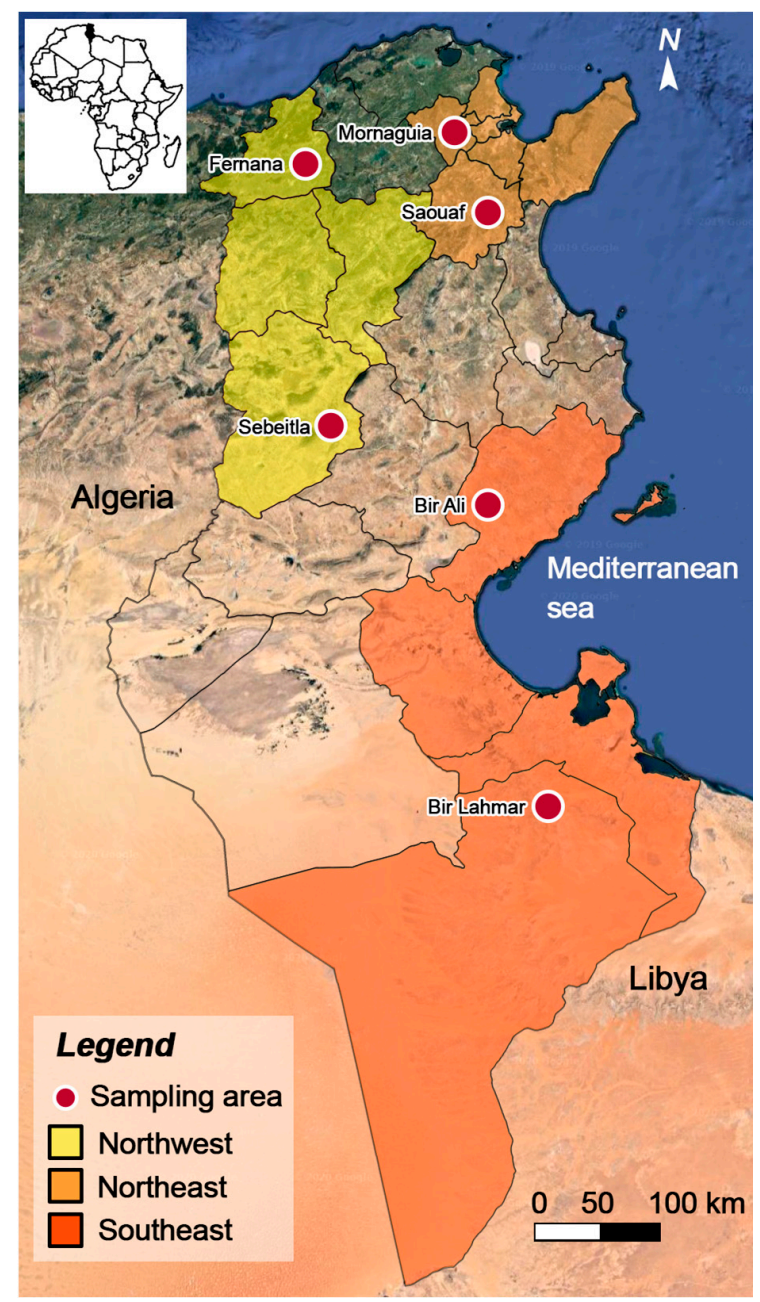

Figure 1. Map of Tunisia showing the sampling areas in the three regions.

Table 1. Characteristics of the surveyed sheep flocks.

\begin{tabular}{ccccc}
\hline Region & Locality (District) & $\begin{array}{c}\text { Number of Surveyed } \\
\text { Farms (Total Number } \\
\text { of Animals) }\end{array}$ & $\begin{array}{c}\text { Number of Barbarine Sheep } \\
\text { in the Region/Total Number } \\
\text { of Barbarine Sheep (\%) }\end{array}$ & $\begin{array}{c}\text { Number of QFO Sheep in the } \\
\text { Region/Total Number of } \\
\text { QFO Sheep (\%) }\end{array}$ \\
\hline Northeast & $\begin{array}{c}\text { Mornaguia (Manouba) } \\
\text { and Saouef (Zaghouan) }\end{array}$ & $6(164)$ & $123 / 288(42.7)$ & $41 / 151(27.1)$ \\
Northwest & $\begin{array}{c}\text { Fernana (Jendouba) and } \\
\text { Sebeitla (Kasserine) }\end{array}$ & $6(162)$ & $119 / 288(41.3)$ & $43 / 151(28.5)$ \\
Southeast & $\begin{array}{c}\text { Bir Ali (Sfax) and Bir } \\
\text { Lahmar (Tataouine) }\end{array}$ & $5(113)$ & $46 / 288(16)$ & $67 / 151(44.4)$ \\
Overall & $17(439)$ & $288(100)$ & $151(100)$ \\
\hline
\end{tabular}

QFO: Queue Fine de l'Ouest breed.

The northeast and the southeast regions are part of the Barbarine sheep homeland even though the breed has a nationwide presence because of its very ancient roots in the country. The northwest region is the main concentration area of the QFO breed [29]. However, last decades have seen an increase in the population of this breed spreading to the central and eastern parts of the country, as a result of the market demand for less fatty meat and also because of the suitability of this breed for more intensive, sedentary type of production [30]. 


\subsection{Animals}

Only yearling and older ewes were included in the present study. Four hundred and thirty-nine ewes were ear-tagged and were monitored at 8 sampling rounds. The breed type was determined based on the description reported by Rekik et al. [29]. The sheep belonged to either the Barbarine $(288 ; 65.6 \%)$ or the QFO $(151 ; 34.4 \%)$ breeds (Table 1 ) and were representative of the national distribution of both breeds among the total 4,000,000 female units in Tunisia [31]. Sheep in Tunisia is one of the main sources of red meat in the country $(39.3 \%)(F A O, 2020)$. The most important sheep breed is the indigenous fat-tailed Barbarine (Figure 2), which represents $64 \%$ of the national sheep population. The second most important breed is the Queue Fine de l'Ouest (QFO, Figure 3), known as "Bergui" or "Western Fine Tail", representing 30\% of the existing breeds in the country [32]. The Barbarine breed, locally known as "Nejdi" or "Arab sheep", was introduced from the steppes of Central Asia by the Phoenicians around 400 Before Christ during the Carthaginian period [33]. It is also the origin of the "Tunis" breed in the USA [34] and the Barbaresca Italian breed [35].

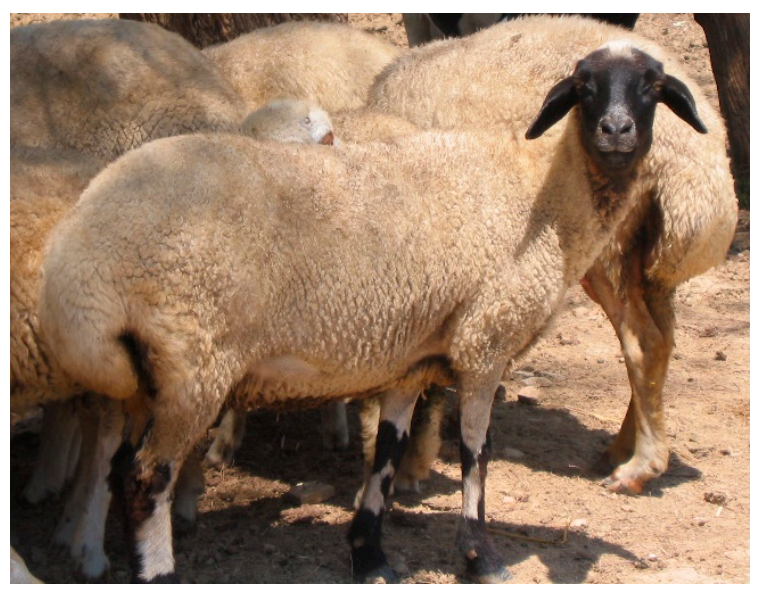

Figure 2. Black-headed Barbarine ewe.

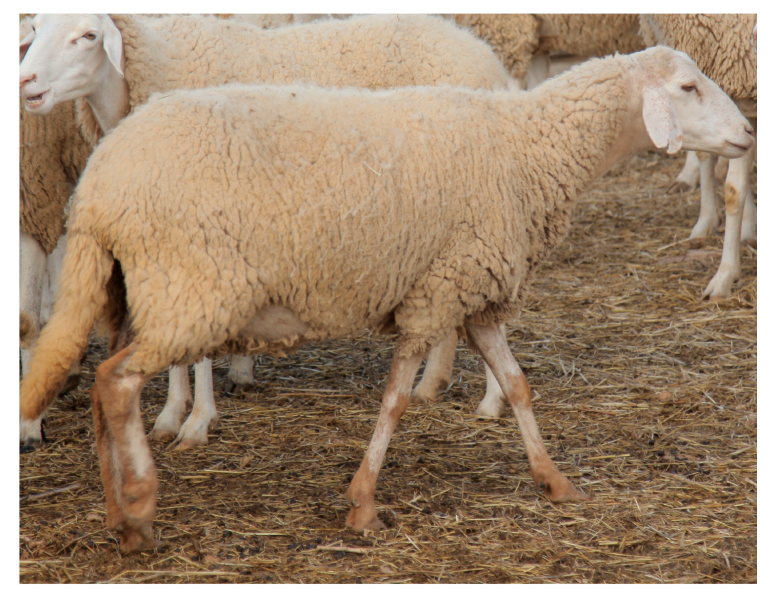

Figure 3. Queue Fine de l'Ouest ewe.

Barbarine sheep are traditionally found in the meridional central and southern steppes of Tunisia; they are also the dominant breed in Libya and expand to eastern Algeria [36]. This sheep breed is generally managed under extensive production systems [37] and is well adapted to the harsh environmental conditions of the country because of the energy reservoir available in the fat tail (1.5 to $7 \mathrm{~kg}$ ) [38]. This breed is (i) tolerant to both warm and cold climates, (ii) resistant to internal and external parasites, (iii) able to use a wide range of low-quality feed resources (shrubby vegetation, cactus, cereal straw, 
olive cake, etc.) [36]. Some authors considered that the Barbarine breed is composed of different ecotypes (strains) [39], but genetic studies did not confirm any difference between subpopulations [40].

QFO sheep are genetically very close and often assimilated to the Ouled Jellal (thintailed) breed mainly encountered in Algeria, but the breed is also present in the western plateaus of Tunisia and the eastern mixed sheep-crop systems of Morocco [29]. Animals of this breed are reared mainly for meat production [37]. This breed has a relatively good adaptation to harsh and dry environmental conditions, but it remains more sensitive to extreme temperatures than the Barbarine breed [41].

Despite the above-mentioned differences, genetic studies showed a close relationship between Barbarine and QFO breeds, presenting a low genetic diversity or variation (high similarity), thus indicating low heterozygosity levels [32,42]. Authors attributed this observed close relationship to a possible cross migration in the past between these two breeds. Short geographic distances between areas where Barbarine and QFO breeds are distributed may allow this cross migration [43].

In extensive flocks, sheep are reared mixed with goats and/or cows; the presence of horses is limited; however, all sheep flocks own dogs as a guard. Sheep graze year-round on natural rangelands and cereal stubbles in summer. Suckling females are supplemented with concentrate, especially during cold winter. Spring is the main mating season, and most births are distributed between September and February. In this kind of extensive sheep flocks, most farmers do not apply acaricide to prevent ectoparasites, but occasionally they treat against gastrointestinal nematodes. Vaccination campaigns are organized once per year by the National Veterinary Services and consist of preventing Brucellosis, bluetongue disease, foot and mouth disease and sheep-pox disease.

\subsection{Sampling and Data Collection}

During each visit, all the selected ewes were clinically examined for their temperature (fever threshold value: $39.5^{\circ} \mathrm{C}$ ), the conjunctival mucosa status: anemic (colored in white or light pink), congested (colored in red), normal (colored in pink), the macroscopic aspect of their feces (pasty or solid) and their body score was estimated from poor (score 1) to excellent (score 5) [44]. Five milliliters of blood were collected from each selected animal in sterile vacutainer EDTA tubes via jugular venipuncture.

As in Tunisian sheep, ticks attach mainly in ears [28]; all the present ticks were collected from both ears of each examined animal and counted. In the laboratory, ticks were stored in $70 \%$ ethanol until identification under a stereomicroscope according to the key of Walker et al. [45].

\subsection{Hematology}

Hematological analyses were performed with Auto Hematology analyzer BC-2800Vet ${ }^{\circledR}$ (Shenzen Mindray BioMedical Electronics Co., Ltd., Shenzhen, China) for all the blood samples. The hematological study included red blood cell count $(\mathrm{RBC})\left(\times 10^{6} / \mathrm{mL}\right)$, hemoglobin $(\mathrm{Hb})(\mathrm{g} / \mathrm{dL})$ and packed cell volume (PCV) $(\%)$. Animals were considered anemic when all the three parameters $\mathrm{RBC}, \mathrm{Hb}$ and $\mathrm{PCV}$, were below the minimum threshold values 9 . $10^{12} / \mathrm{L} ; 9 \mathrm{~g} / \mathrm{dL}$ and $27 \%$, respectively [46].

\subsection{Molecular Analysis for Piroplasms Detection}

Due to limited resources, we performed molecular analyses for samples collected during the first year: 438, 370, 348, and 321 in April 2018, July 2018, October 2018 and January 2019, respectively. Since animals belong to private farmers, and we did not interfere with the existing management, some animals were not present at subsequent sampling rounds because they were sold, died or transferred to other flocks. Prior to PCR, the DNA was extracted from total blood. 


\subsubsection{DNA Extraction}

The total DNA was extracted from $300 \mu \mathrm{L}$ anti-coagulated blood using a rapid blood genomic DNA extraction kit (Ref.: BT4782, Bio Basic, Markham, Canada). All the DNA extraction steps were applied as recommended by the manufacturer, except for two steps. Indeed, after adding protein precipitation solution, the samples were placed at $-20{ }^{\circ} \mathrm{C}$ for $45 \mathrm{~min}$ instead of the $20 \mathrm{~min}$ recommended by the manufacturer, followed by centrifugation at $16,000 \times g$ instead of $12,000 \times g$. This step was repeated if the obtained pellet still contained protein. Extracted DNA was double-aliquoted and stored at $-20^{\circ} \mathrm{C}$ until further analyses. The quality of extracted DNA was checked by universal polymerase chain reaction $(\mathrm{PCR})$.

\subsubsection{Polymerase Chain Reactions}

To verify the presence and the integrity of DNA in each extract, a set of universal primers 1A and 564R (Table 2), targeting simultaneously the 18S and the 16S ribosomal RNAs genes of eukaryotic and prokaryotic organisms, respectively, were used according to the protocol of Wang et al. [47]. This universal PCR was carried out in $25 \mu \mathrm{L}$ reaction volume consisting of $1 \times$ PCR buffer, $2 \mathrm{mM} \mathrm{MgCl}_{2}, 10 \mu \mathrm{M}$ of each primer, $0.2 \mathrm{mM}$ of each dNTP, $2 \mathrm{U}$ Taq polymerase (Vivantis, Chino, CA, USA), and $1.5 \mu \mathrm{L}$ of DNA template. The following cycling profile was used: initial denaturation for $5 \mathrm{~min}$ at $94{ }^{\circ} \mathrm{C}$, followed by 25 cycles $\left(94^{\circ} \mathrm{C}, 59^{\circ} \mathrm{C}\right.$ and $72{ }^{\circ} \mathrm{C}$ for $50 \mathrm{~s}$ each) and a final extension at $72{ }^{\circ} \mathrm{C}$ for $10 \mathrm{~min}$, and holding temperature of $4{ }^{\circ} \mathrm{C}$ at the end of the run.

Table 2. Primers used for universal and piroplasms detection PCRs.

\begin{tabular}{ccc}
\hline Primers & Sequences $\left(5^{\prime}-\right.$-----3') $^{\prime}$ ) & Author \\
\hline 1A & AACCTGGTTGATCCTGCCAGT & {$[47]$} \\
564R & GGCACCAGACTTGCCCTC & \\
RLB-F & GAGGTAGTGACAAGAAATAACAATA & {$[48]$} \\
RLB-R & TCTTCGATCCCCTAACTTTC & \\
\hline
\end{tabular}

To detect a common sequence ARNr18S to both Babesia and Theileria genera, catch-all primers (RLB F and RLB R) (Table 2) were used on samples that were positive in the Universal PCR. Reactions were performed in $25 \mu \mathrm{L}$ volume containing $19 \mu \mathrm{L}$ PCR buffer, $1.5 \mathrm{mM} \mathrm{MgCl} 2,200 \mu \mathrm{M}$ of each deoxyribonucleotide triphosphate, $0.125 \mu \mathrm{g}$ of Taq hot start $\mathrm{Ab}, 0.1 \mathrm{U}$ of Uracil DNA glycosylase, $2.5 \times 10^{-5} \mu \mathrm{M}$ of each primer and $1.25 \mathrm{U}$ of Super Taq DNA polymerase (Vivantis, Chino, CA, USA) and $3 \mu \mathrm{L}$ of sampled DNA [48]. The DNA of pure culture of Theileria annulata and sterile water were used as positive and negative controls, respectively. The cycling conditions consisted of an initial denaturation of $5 \mathrm{~min}$ at $94{ }^{\circ} \mathrm{C}$, followed by 8 cycles (denaturation at $94{ }^{\circ} \mathrm{C}$ for $20 \mathrm{~s}$, followed by annealing at $67^{\circ} \mathrm{C}$ for $30 \mathrm{~s}$, and elongation at $72{ }^{\circ} \mathrm{C}$ for $30 \mathrm{~s}$ ). The annealing temperature was decreased by $2{ }^{\circ} \mathrm{C}$ every two cycles (from $67^{\circ} \mathrm{C}$ to $59^{\circ} \mathrm{C}$ ). The previous step was followed by 40 cycles (denaturation at $94{ }^{\circ} \mathrm{C}$ for $20 \mathrm{~s}$, followed by annealing at $57^{\circ} \mathrm{C}$ for $30 \mathrm{~s}$, and elongation at $72{ }^{\circ} \mathrm{C}$ for $30 \mathrm{~s}$ ) and a final extension of $7 \mathrm{~min}$ at $72{ }^{\circ} \mathrm{C}$. At the end of the run, the holding temperature was about $4{ }^{\circ} \mathrm{C}$.

The PCR products were examined by electrophoresis on $1.5 \%$ agarose gel stained with ethidium bromide and visualized under ultraviolet light. The size of the amplified fragment is about $460-520 \mathrm{pb}$.

\subsection{Statistical Analyses}

The following epidemiological indicators [49] were estimated:

Tick infestation prevalence $(\%)=100 \times($ Number of infested sheep/Total number of examined sheep)

Mean intensity $\left(\mathrm{m}_{\mathrm{i}}\right)=$ number of ticks/total number of infested sheep

Mean abundance $\left(\mathrm{m}_{\mathrm{a}}\right)=$ number of ticks $/$ total number of examined animals 
The molecular prevalence of Babesia/Theileria infection (\%) was calculated as $100 \times$ (number of PCR positive sheep/total number of tested sheep).

For the total period from April 2018 to January 2019, the total number of infected animals is different from the total positive Babesia/Theileria because each positive animal was counted one time even if found infected more than once.

All data were analyzed using SPSS 21 software (IBM, New York, NY, USA). The 95\% confidence intervals for proportions and means were estimated, according to Schwartz [50]. For comparison between proportions in large and small samples, the chi-squared test $\left(\chi^{2}\right)$ and Fisher's exact test were used, respectively. For the between months comparison of the mean intensity and the mean abundance, one-way ANOVA was performed followed by post hoc Tukey's test. The correlation between tick counts and hematological parameters was tested by the coefficient of Pearson's (r). To test the effect of breed on tick infestation prevalence, a binary logistic regression was applied.

As an initial Poisson regression of tick count showed overdispersion, a negative binomial regression model was applied [51]. In this model, the tick count was considered the dependent variable, while both the region and the breed as predictor factors. The interaction between breed and region was also considered in the model. All statistical tests were considered significant at a threshold of 0.05 .

\subsection{Ethics Statement}

The animals sampled in this study were owned by private sheep farmers. The sheep owners were aware of the objectives of the study, and the animals were sampled with their permission, in their presence and with the supervision of a qualified veterinarian. The sampling procedures were performed according to the guidelines for the care and use of animals of the National School of Veterinary Medicine, Tunisia. During or after the sampling process, no animal was injured or dead, no female aborted.

\section{Results}

\subsection{Overall, Collected Tick Population and Overall Parasitological Indicators}

During the 8 sampling rounds, all the ticks collected from examined ewes $(\mathrm{n}=707)$ were adults. The dominant tick species was Rhipicephalus sanguineus s.l. $(91.4 \%$; 646/707) followed by Hyalomma impeltatum $(4.4 \%$; 31/707), Hyalomma excavatum $(2.1 \%$; 15/707), Hyalomma marginatum $(0.7 \% ; 5 / 707)$, Hyalomma dromedarii $(0.6 \% ; 4 / 707)$ and Rhipicephalus annulatus $(0.3 \% ; 2 / 707)(p<0.001)$ (Table 3$)$.

Table 3. Distribution according to sheep breed of tick species collected during 8 sampling rounds.

\begin{tabular}{cccc}
\hline \multirow{2}{*}{ Tick Species } & \multicolumn{3}{c}{ Number of Ticks in the Breed (\%) $^{\mathbf{a}}$} \\
\cline { 2 - 4 } & Barbarine & Queue Fine de 1'Ouest & Overall (\%) \\
\hline Rhipicephalus sanguineus s.l. & $487(75.4)$ & $159(24.6)$ & $646(91.4)^{\mathrm{b}}$ \\
Hyalomma impeltatum & 31 & 0 & $31(4.4)$ \\
Hyalomma excavatum & 15 & 0 & $15(2.1)$ \\
Hyalomma marginatum & 5 & 0 & $5(0.7)$ \\
Hyalomma dromedarii & 4 & 0 & $4(0.6)$ \\
Rhipicephalus bursa & 2 & 1 & $3(0.4)$ \\
Rhipicephalus annulatus & 2 & 0 & $2(0.3)$ \\
Haemaphysalis sulcata & 1 & 0 & $1(0.1)$ \\
\hline Overall (\%) & $547(77.4)^{\mathrm{c}}$ & $160(22.6)$ & $707(100)$ \\
\hline
\end{tabular}

a $\%$ not calculated for denominator $<35 ;{ }^{b}$ Overall, percentages between the different tick species are significantly different at $p \leq 0.001$ using $\chi^{2}$ test; ${ }^{c}$ Overall, percentages between sheep breeds are significantly different at $p \leq 0.001$ using $\chi^{2}$ test.

During the total period of sampling, almost $45 \%$ (317/707) of ticks were collected from the southeast region, whereas $42 \%(296 / 707)$ and $13 \%$ (94/707) were collected from the northeast and the northwest, respectively. 
The between months distribution of ticks was more important for abundance compared to intensity (Tables 4 and 5).

The highest and lowest overall tick infestation prevalences occurred in July 2019 $(34 \pm 2.8)$ and in January $2019(1.8 \pm 0.7)$, respectively $(p<0.001)$ (Table 4$)$. The highest mean intensity $(92 / 23 ; 4)$ occurred in October 2019 , whereas the lowest occurred in October $2018(20 / 18 ; 1.11)$ (Table 4$)$. The highest $(215 / 288 ; 0.75 \pm 0.09)$ and lowest $(9 / 341 ; 0.03 \pm 0.01)$ means' abundance was estimated in July and January 2019 , respectively (Table 4).

The highest prevalences were recorded in April and July of both 2018 and 2019 in the northeast. During the visits of October and January 2019 and 2020, the highest prevalences were recorded in the southeast (Figure 4, Table S1).

Table 4. Mean temperature and cumulative precipitation of the 15 days before tick collections in the three regions and corresponding overall tick infestation prevalence, intensity and abundance during the 8 sampling rounds.

\begin{tabular}{|c|c|c|c|c|c|c|c|c|c|}
\hline Variables & April 2018 & July 2018 & October 2018 & January 2019 & April 2019 & July 2019 & October 2019 & January 2020 & $p$ \\
\hline \multicolumn{10}{|l|}{ Northeast } \\
\hline $\begin{array}{c}\text { Mean } \\
\text { temperature } \\
\left({ }^{\circ} \mathrm{C}\right) \\
(\text { Min-Max })^{\mathrm{a}}\end{array}$ & $\begin{array}{c}15.05 \\
(9.7-207)\end{array}$ & $\begin{array}{c}27.34 \\
(21.09-34.25)\end{array}$ & $\begin{array}{c}21.48 \\
(17.2-26.73)\end{array}$ & $\begin{array}{c}10.11 \\
(6.44-14.04)\end{array}$ & $\begin{array}{c}13.58 \\
(8.93-18.86)\end{array}$ & $\begin{array}{c}27.96 \\
(21.65-34.32)\end{array}$ & $\begin{array}{c}21.61 \\
(16.68-27.03)\end{array}$ & $\begin{array}{c}9.87 \\
(6.12-13.99)\end{array}$ & N.A. \\
\hline $\begin{array}{c}\text { Cumulative } \\
\text { precipitation } \\
(\mathrm{mm})^{\mathrm{b}}\end{array}$ & 16.44 & 0.5 & 8.02 & 17.12 & 44.32 & 1.58 & 19.39 & 14.43 & \\
\hline \multicolumn{10}{|l|}{ Northwest } \\
\hline $\begin{array}{c}\text { Mean } \\
\text { temperature } \\
\left({ }^{\circ} \mathrm{C}\right) \\
\text { (Min-Max) }\end{array}$ & $\begin{array}{c}12.48 \\
(7.31-18.23)\end{array}$ & $\begin{array}{c}22.66 \\
(17.43-30.53)\end{array}$ & $\begin{array}{c}20.21 \\
(15.93-25-45)\end{array}$ & $\begin{array}{c}8.02 \\
(3.91-11.27)\end{array}$ & $\begin{array}{c}11.17 \\
(6.81-15.99)\end{array}$ & $\begin{array}{c}27.48 \\
(20.72-33.99)\end{array}$ & $\begin{array}{c}20.80 \\
(15.04-27.07)\end{array}$ & $\begin{array}{c}9.71 \\
(6.36-13.16)\end{array}$ & N.A. \\
\hline $\begin{array}{l}\text { Cumulative } \\
\text { precipitation } \\
(\mathrm{mm})\end{array}$ & 40.44 & 4.22 & 43.99 & 33.06 & 56.06 & 1.73 & 15.37 & 17.5 & \\
\hline \multicolumn{10}{|l|}{ Southeast } \\
\hline $\begin{array}{c}\text { Mean } \\
\text { temperature } \\
\left({ }^{\circ} \mathrm{C}\right) \\
\text { (Min-Max) }\end{array}$ & $\begin{array}{c}17.62 \\
(12.12-23.35)\end{array}$ & $\begin{array}{c}28.7 \\
(22.69-35.26)\end{array}$ & $\begin{array}{c}23.55 \\
(19.11-28.71)\end{array}$ & $\begin{array}{c}10.97 \\
(13.07-15.52)\end{array}$ & $\begin{array}{c}15.05 \\
(11.06-19.57)\end{array}$ & $\begin{array}{c}30.9 \\
(24.88-37.80)\end{array}$ & $\begin{array}{c}24.4 \\
(19.9-29.63)\end{array}$ & $\begin{array}{c}10 \\
(6.83-13.52)\end{array}$ & N.A. \\
\hline $\begin{array}{l}\text { Cumulative } \\
\text { precipitation } \\
(\mathrm{mm})\end{array}$ & 6 & 1.6 & 19.8 & 5 & 27.17 & 0 & 14.08 & 16.93 & \\
\hline $\begin{array}{l}\text { Infestation } \\
\text { prevalence }^{c}\end{array}$ & $53 / 439$ & $44 / 382$ & $18 / 362$ & $6 / 341$ & $60 / 269$ & $98 / 288$ & $23 / 272$ & $19 / 258$ & $<0.001^{\mathrm{f}}$ \\
\hline$(\% \pm \mathrm{SE})$ & $(12.1 \pm 1.6)$ & $(11.5 \pm 1.6)$ & $(5 \pm 1.1)$ & $(1.8 \pm 0.7)$ & $(22.3 \pm 2.5)$ & $(34 \pm 2.8)$ & $(8.5 \pm 1.7)$ & $(7.4 \pm 1.6)$ & \\
\hline $\begin{array}{c}\text { Mean } \\
\text { intensity }\end{array}$ & $129 / 53$ & $61 / 44$ & $20 / 18$ & $9 / 6$ & $135 / 60$ & $215 / 98$ & $92 / 23$ & $46 / 19$ & $<0.001 \mathrm{~g}$ \\
\hline$\left(m_{i} \pm S E\right)$ & $(2.43 \pm 0.2)$ & $(1.39 \pm 0.09)$ & $(1.11 \pm 0.07)$ & $(1.5 \pm 0.22)$ & $(2.25 \pm 0.22)$ & $(2.19 \pm 0.19)$ & $(4 \pm 1.16)$ & $(2.42 \pm 0.3)$ & \\
\hline $\begin{array}{c}\text { Mean } \\
\text { abundance }\end{array}$ & $129 / 439$ & $61 / 382$ & $20 / 362$ & $9 / 341$ & $135 / 269$ & $215 / 288$ & $92 / 272$ & $46 / 258$ & $<0.001^{\mathrm{h}}$ \\
\hline$\left(\mathrm{m}_{\mathrm{a}} \pm \mathrm{SE}\right)$ & $(0.29 \pm 0.05)$ & $(0.16 \pm 0.02)$ & $(0.06 \pm 0.01)$ & $(0.03 \pm 0.01)$ & $(0.5 \pm 0.07)$ & $(0.75 \pm 0.09)$ & $(0.34 \pm 0.11)$ & $(0.18 \pm 0.04)$ & \\
\hline
\end{tabular}

SE: standard error; ${ }^{\mathrm{a}, \mathrm{b}}$ The mean temperature and the cumulative precipitation were estimated for the 15 days before the tick collection date in each region (crude data were extracted from https://developers.google.com/earth-engine/datasets); N.A.: not applicable; ${ }^{\mathrm{c}}$ number of infested sheep/total number of examined sheep; ${ }^{\mathrm{d}}$ number of collected ticks/Total number of infested sheep; ${ }^{\mathrm{e}}$ number of collected ticks/total number of examined sheep; ${ }^{\mathrm{f}}$ the $p$ value was estimated using $\chi^{2}$ test to compare the infestation prevalences between the 8 sampling rounds; ${ }^{g, h}$ the $p$ values were estimated by using ANOVA test and Tukey's test to compare the means between the 8 sampling rounds. 
Table 5. Multiple comparisons of the mean tick abundance and mean tick intensity according to the eight sampling rounds using the Tukey's test.

\begin{tabular}{|c|c|c|c|c|c|c|c|c|}
\hline & April 2018 & July 2018 & October 2018 & January 2019 & April 2019 & July 2019 & October 2019 & January 2020 \\
\hline \multicolumn{9}{|c|}{ Mean Tick Abundance } \\
\hline April 2018 & 1 & 0.35 & 0.009 & 0.003 & 0.08 & 0.001 & 1 & 0.61 \\
\hline July 2018 & - & 1 & 0.87 & 0.67 & 0.001 & 0.001 & 0.47 & 1 \\
\hline October 2018 & - & - & 1 & 1 & 0.001 & 0.001 & 0.028 & 0.87 \\
\hline January 2019 & - & - & - & 1 & 0.001 & 0.001 & 0.011 & 0.7 \\
\hline April 2019 & - & - & - & - & 1 & 0.445 & 0.196 & 0.001 \\
\hline July 2019 & - & - & - & - & - & 1 & 0.001 & 0.001 \\
\hline October 2019 & - & - & - & - & - & - & 1 & 0.69 \\
\hline January 2020 & - & - & - & - & - & - & - & 1 \\
\hline \multicolumn{9}{|c|}{ Mean Tick Intensity } \\
\hline April 2018 & 1 & 0.15 & 0.27 & 0.96 & 1 & 0.96 & 0.15 & 1 \\
\hline July 2018 & - & 1 & 1 & 1 & 0.24 & 0.54 & 0.001 & 0.68 \\
\hline October 2018 & - & - & 1 & 1 & 0.37 & 0.64 & 0.002 & 0.65 \\
\hline January 2019 & - & - & - & 1 & 0.98 & 0.99 & 0.24 & 0.98 \\
\hline April 2019 & - & - & - & - & 1 & 0.99 & 0.08 & 1 \\
\hline July 2019 & - & - & - & - & - & 1 & 0.009 & 1 \\
\hline October 2019 & - & - & - & - & - & - & 1 & 0.32 \\
\hline January 2020 & - & - & - & - & - & - & - & 1 \\
\hline
\end{tabular}

Significant values using one-way ANOVA followed by Tukey's test are $p \leq 0.05$.

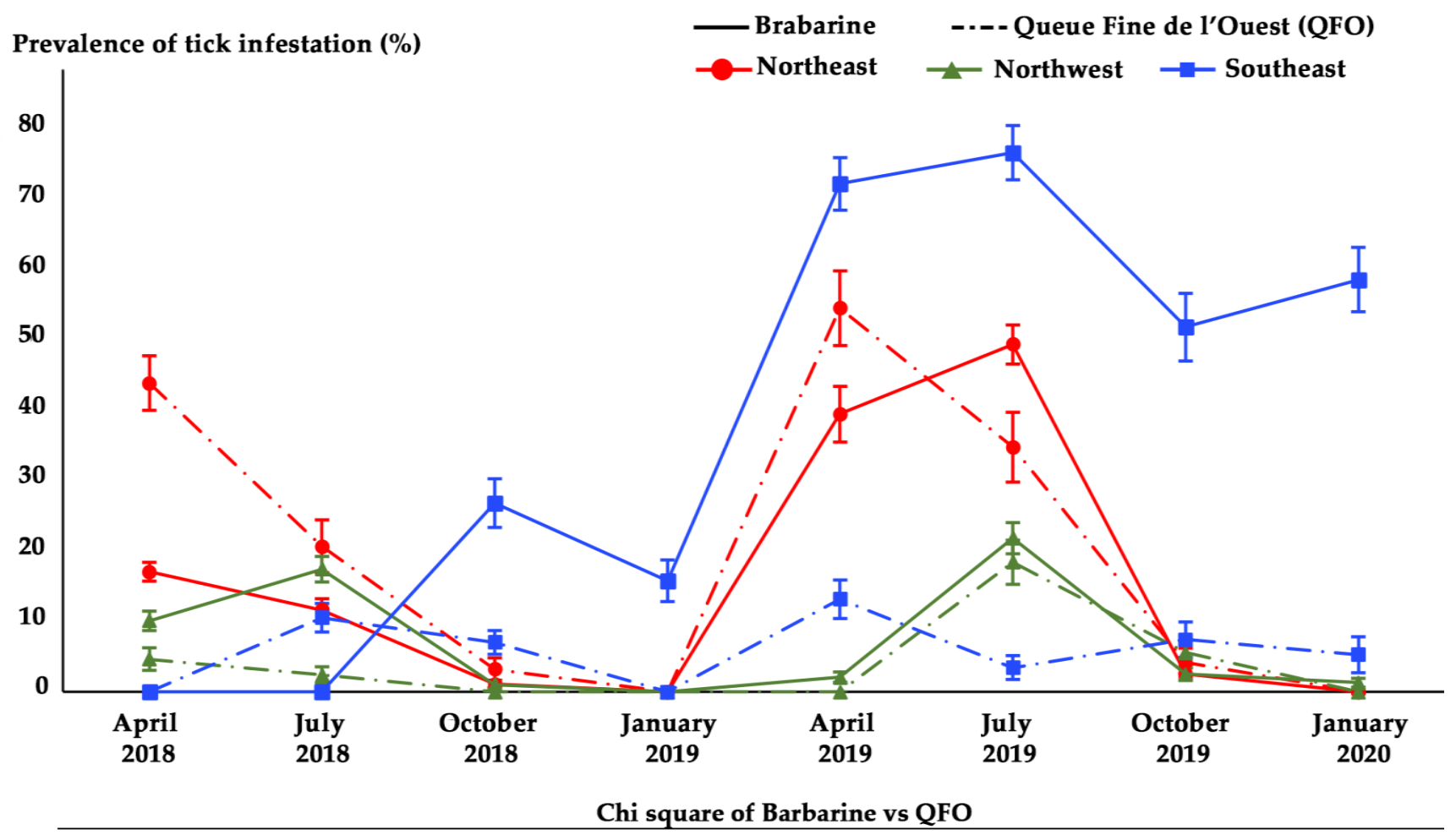

Northeast Sig.

\begin{tabular}{llllllll}
\hline Northwest & Sig. & & & & & & \\
\hline \\
Southeast & & Sig. & Sig. & Sig. & Sig. & Sig. & Sig. \\
\hline
\end{tabular}

Figure 4. Tick infestation prevalence according to regions and sheep breeds during the eight sampling rounds. Bars: standard errors; Sig.: statistically significant infestation prevalences difference between sheep breeds using the $\chi^{2}$ test. 


\subsection{Breed Differences in Tick Infestation}

\subsubsection{Tick Species Distribution}

The majority of ticks were collected from Barbarine when compared to QFO ewes (77.4\% and 22.6\%, respectively) ( $p<0.001)$. More than $70 \%$ of the ticks infesting Barbarine sheep were Rhipicephalus sanguineus s.l. (Table 3). All the Hyalomma spp. tick species (55/707) and one male Haemaphysalis sulcata specimen were collected only from Barbarine ewes (Table 3).

\subsubsection{Tick's Infestation Prevalence According to Sheep Breed and Region}

Regardless of the region, Barbarine ewes were more infested than QFO ewes $(p \leq 0.05)$ in July 2019 and January 2020 (Figures 4 and 5), with the same trend for mean abundance (Figure 6). The mean intensity was higher for Barbarine sheep during all the sampling months of 2019 and 2020, except for April (Figure 7).

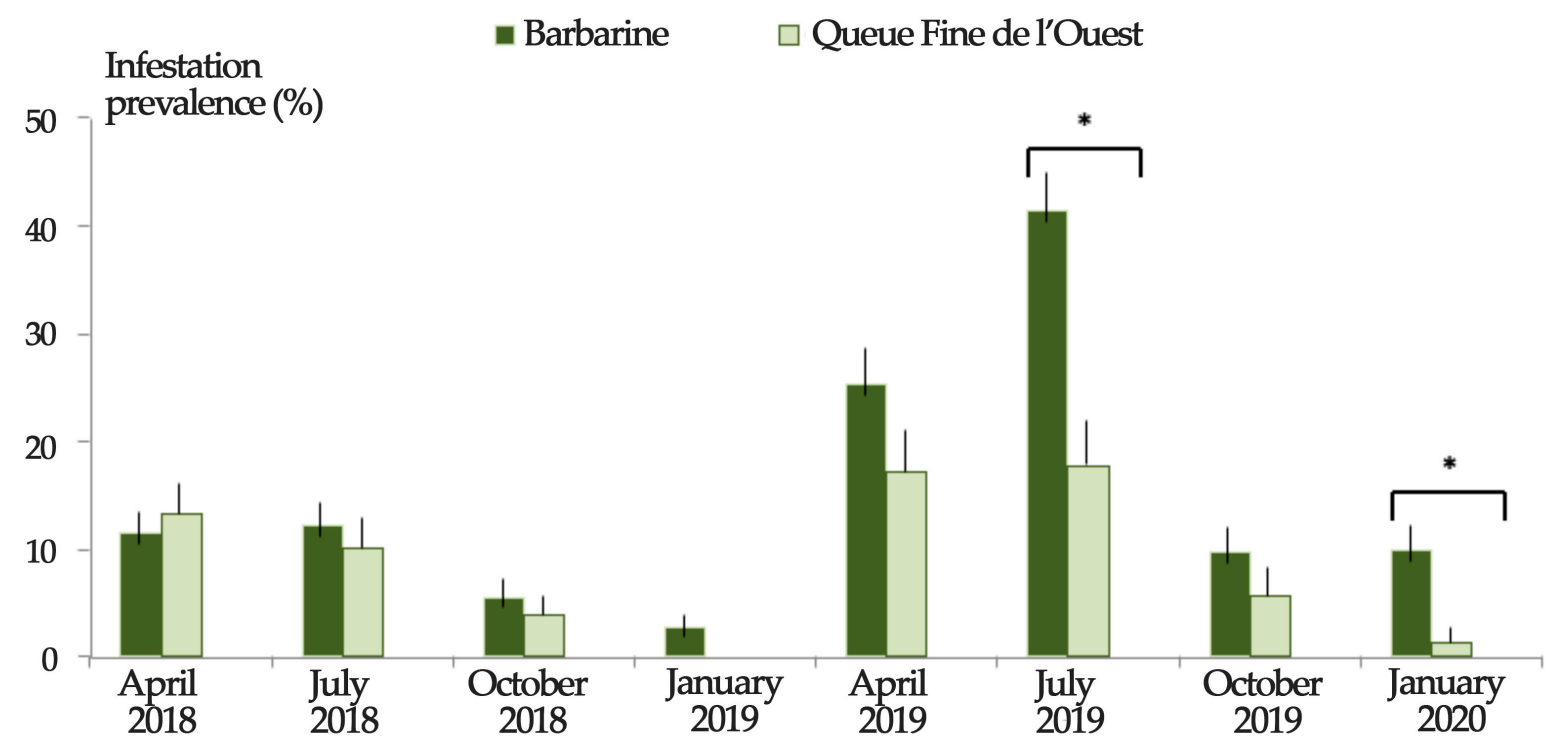

Figure 5. Tick infestation prevalence among two sheep breeds in Tunisia during 8 successive sampling rounds. * Statistically significant infestation prevalences difference between sheep breeds at $p \leq 0.05$ using $\chi^{2}$ test. Bars: standard error.

n Barbarine $\quad \square$ Queue Fine de l'Ouest

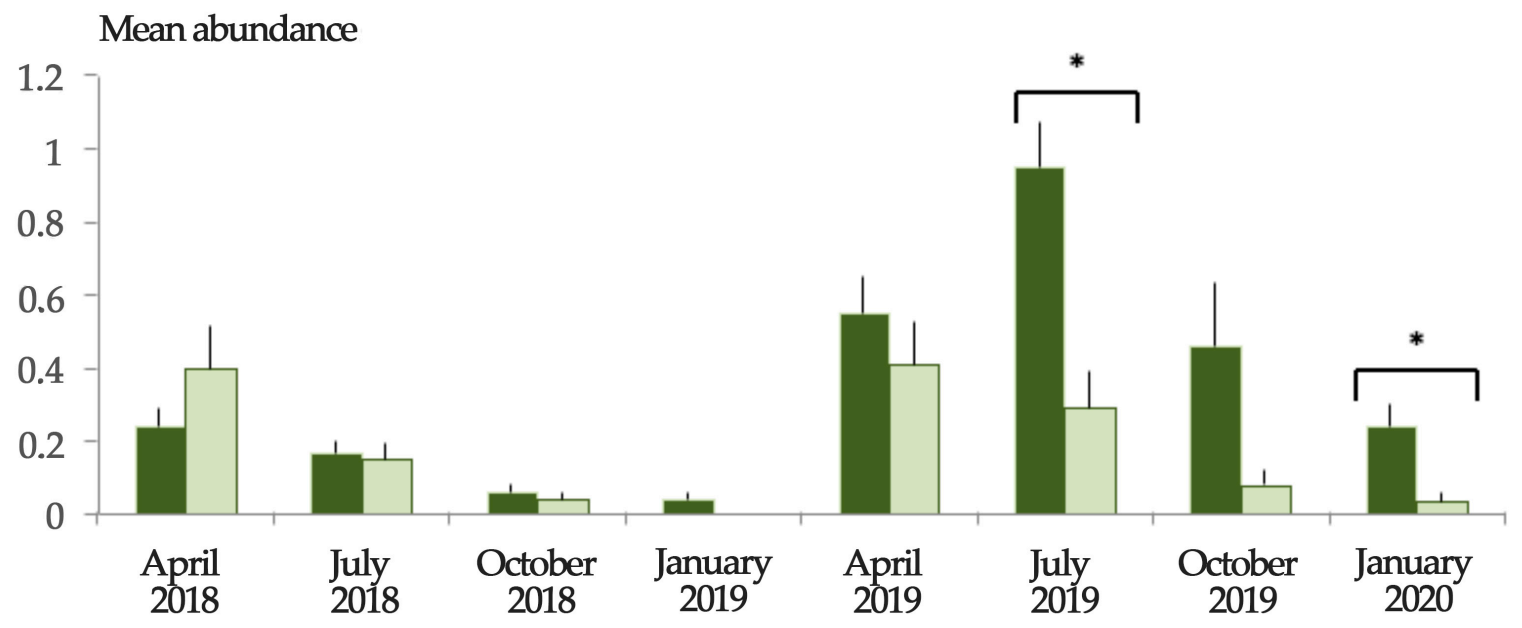

Figure 6. Tick abundance among two sheep breeds in Tunisia during 8 successive sampling rounds. * Statistically significant mean abundance difference between sheep breeds at $p \leq 0.05$ threshold using $\chi^{2}$ test. Bars: standard error. 
- Barbarine $\quad \square$ Queue Fine de l'Ouest

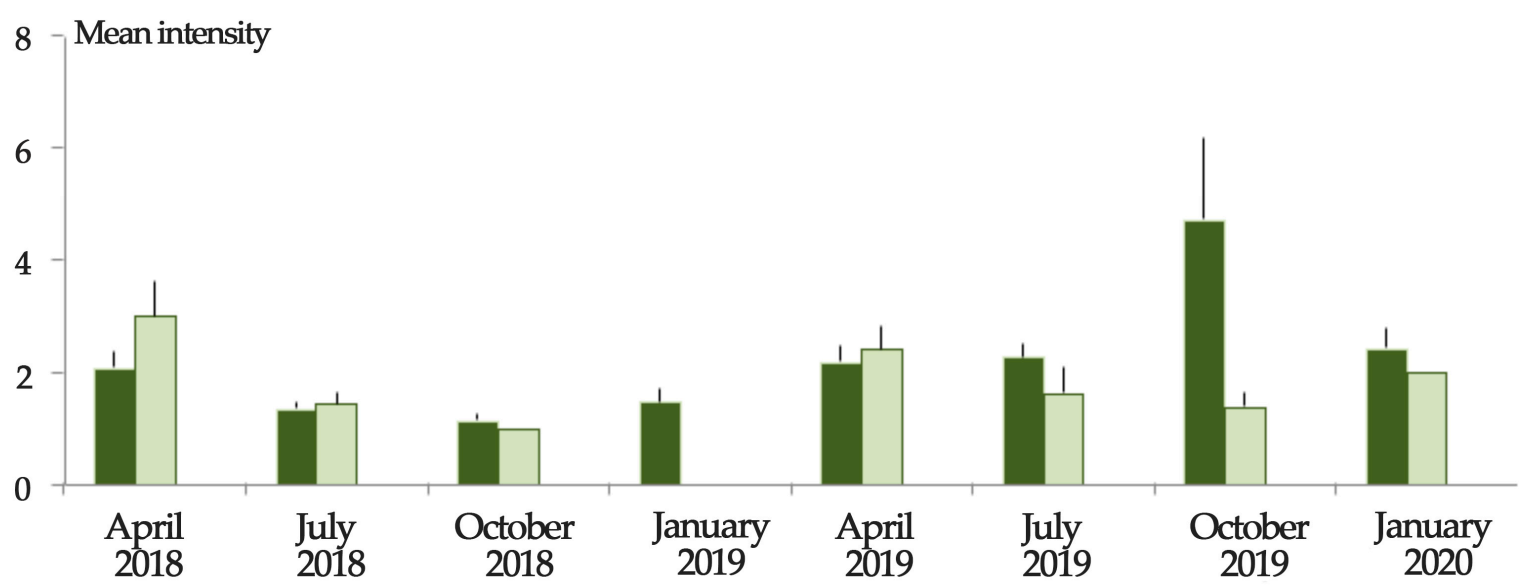

Figure 7. Tick infestation intensity among two sheep breeds in Tunisia during 8 successive sampling rounds. Bars: standard error.

Taking the regions into account, Barbarine ewes from the southeast showed significantly higher infestation prevalence than QFO breed starting from October 2018 and the subsequent sampling rounds (Figure 4, Table S1). In the northwest region, the same trend was only noted in July 2018 when prevalences of $17.4 \%(19 / 109)$ and $2.4 \%(1 / 42)$ were recorded for Barbarine and QFO, respectively. In the northeast, the estimated prevalence of infestation was significantly higher in QFO than Barbarine ewes only during April 2018, with $44 \%(18 / 41)$ and $17 \%(21 / 123)$, respectively (Figure 4, Table S1). When using a binary logistic regression, the QFO sheep had less risk (odds ratio $=0.58$; $95 \%$ CI: $(0.44-0.78)$ ) to be infested by ticks than the Barbarine sheep breed.

As demonstrated by the negative binomial regression model, "breed", "region," and the interaction "region $\times$ breed" factors explained the tick count in July 2018, April and July 2019 (Table 6).

Table 6. P values from the negative binomial regression model to test the tick count as a dependent variable with the region, breeds, and their interaction as predictors.

\begin{tabular}{|c|c|c|c|c|c|c|c|c|}
\hline & April 2018 & July 2018 & October 2018 & January 2019 & April 2019 & July 2019 & October 2019 & January 2020 \\
\hline $\begin{array}{c}\text { Region } \\
\text { NE } \\
\text { NW } \\
\mathrm{SE}^{\mathrm{R}}\end{array}$ & $\begin{array}{l}\text { N.S. } \\
\text { N.S. }\end{array}$ & $\begin{array}{l}\text { N.S. } \\
\text { N.S. }\end{array}$ & $\begin{array}{l}\text { N.S. } \\
<0.001\end{array}$ & $\begin{array}{l}\text { N.S. } \\
\text { N.S. }\end{array}$ & $\begin{array}{c}0.001 \\
<0.001\end{array}$ & $\begin{array}{l}0.003 \\
\text { N.S. }\end{array}$ & $\begin{array}{l}\text { N.S. } \\
\text { N.S. }\end{array}$ & $\begin{array}{l}\text { N.S. } \\
<0.001\end{array}$ \\
\hline $\begin{array}{c}\text { Breed } \\
\text { Barbarine } \\
\mathrm{QFO}^{\mathrm{R}}\end{array}$ & N.S. & $<0.001$ & 0.02 & N.S. & $<0.001$ & $<0.001$ & $<0.001$ & 0.001 \\
\hline $\begin{array}{c}\text { Region } \times \text { Breed } \\
\mathrm{NE} \times \text { Barbarine } \\
\mathrm{NE} \times \mathrm{QFO}^{\mathrm{R}} \\
\mathrm{NW} \times \text { Barbarine } \\
\mathrm{NW} \times \mathrm{QFO}^{\mathrm{R}} \\
\mathrm{SE} \times \text { Barbarine } \\
\mathrm{SE} \times \mathrm{QFO}^{\mathrm{R}}\end{array}$ & N.S. & $<0.001$ & N.S. & N.S. & $<0.001$ & 0.001 & $\begin{array}{c}0.01 \\
<0.001\end{array}$ & N.S. \\
\hline
\end{tabular}

R: Reference modality; QFO: Queue Fine de l'Ouest sheep breed; NE: northeast; NW: northwest; SE: southeast; N.S.: not significant; empty cells: not applicable for the reference modality and when the value of $\mathrm{B}=0$ ).

\subsection{Molecular Prevalence of Piroplasms}

The overall molecular prevalence in tested ewes was estimated at $2.37 \pm 0.4 \%(35 / 1477)$; 21 ewes were infected at least once during the whole period. Eleven sheep out of the 21 were infected during one season, while 6, 3 and 1, were infected in two, three and four successive seasons, respectively. All the infected sheep $(n=21)$ were from the Barbarine breed; no piroplasms were detected in QFO ewes during the whole sampling period (Table 7). The 
highest molecular prevalence occurred during October 2018 (13/2019), while in April 2018 and January 2019, only 2 and 8 ewes were infected, respectively. The infection prevalence with piroplasms was different between the three regions, and when taking the sampling rounds altogether, $14.6 \%(24 / 164), 5 \%(8 / 161)$ and $2.7 \%(3 / 113)$ were recorded from the northeast, northwest and southeast, respectively $(p \leq 0.05)$.

Table 7. Breed differences for molecular prevalence to Theileria/Babesia during four consecutive sampling rounds.

\begin{tabular}{|c|c|c|}
\hline \multirow[t]{2}{*}{ Sampling Round } & \multicolumn{2}{|c|}{$\begin{array}{c}\text { Number of Theileria-Babesia Positive Sheep/Number of } \\
\text { Examined Sheep }(\% \pm \text { SE })\end{array}$} \\
\hline & Barbarine & Queue Fine de L'Ouest \\
\hline April 2018 & $2 / 286(0.7 \pm 0.5)^{a}$ & $0 / 152(0)^{b}$ \\
\hline July 2018 & $12 / 242(4.96 \pm 1.4)$ & $0 / 128(0)$ \\
\hline October 2018 & $13 / 219(5.94 \pm 1.6)$ & $0 / 129(0)$ \\
\hline January 2019 & $8 / 208(3.85 \pm 1.3)$ & $0 / 113(0)$ \\
\hline Total & $35 / 955(3.66 \pm 0.6)$ & $0 / 522(0)$ \\
\hline
\end{tabular}
different at $p \leq 0.01$ using $\chi^{2}$ test; $^{\text {b }}$ Statistics not applicable.

The percentage of ewes with anemia ranged between 0.44\% (2/453) in April 2018 to $3.04 \%(11 / 362)$ in July $2018(p=0.01)$. There was no significant correlation between anemia and tick count, positivity to piroplasms, age, and breeds for all the sampling rounds.

\section{Discussion}

The current study highlights that the Queue Fine de l'Ouest breed showed a marked lower tick infestation and no piroplasms infection, compared to Barbarine ewes. This may be an indicator of the existence of a form of genetic variability among sheep breeds in Tunisia with regards to infestation by ticks and TBP. The very low infestation of QFO sheep by ticks between July 2018 and January 2020 and the absence of any animal of this breed infected with piroplasms should be confirmed using experimental tick infestation protocol on larger animals' samples.

Sheep in Tunisia are facing several pathogens that hamper the development of the whole small ruminant sector and impede the small farmers to access the market [52]. Several parasites affect sheep health and induce high economic losses either through abortion such as Toxoplasma gondii [53] and Neospora caninum [54] or through general health deterioration caused by gastrointestinal nematodes [55], lungworms [56] and tick-borne pathogens.

\subsection{Breed Differences}

Available reports on sheep tick infestation in Tunisia are very scanty for any consistent comparisons to be made between breeds. A study by Elati et al. [28] indicated that Barbarine sheep were more resistant to tick infestation than QFO animals, which is contradictory to our findings. Indeed, the results of Elati et al. [28] were not representative of the two breeds in the country and their dominant management systems because the sampling was limited to large flocks under intensive management in one single location in northwest Tunisia.

We, therefore, anticipate that the results obtained in our study reflect much better differences between the two breeds because (i) both breeds were sampled in their actual areas of expansion in the country, (ii) targeted flocks had a small to medium size under an extensive management system which is typical in the country [29], and (iii) the repeated frequency of sampling over a period of almost 2 years pleads towards better representativeness and quality of the obtained data.

Moreover, in the southeast region, where almost $45 \%$ of total ticks were collected, and during six sampling rounds (from October 2018 to January 2020), Barbarine ewes were 
most infested than QFO ewes. Those animals of both Barbarine and QFO breeds were also kept under the same husbandry conditions, and the difference of infestation between breeds is less likely to be due to confounding factors.

Tick resistance was intensively investigated in cattle, and it was shown that zebu cattle (Bos indicus) were more resistant than taurine cattle (Bos taurus) [57-60]. Both cellular and humoral reactions of zebu infested by ticks confirmed these observations [26,61,62]. Such evidence led to the successful selection of tick resistant cattle as part of cattle-tick control schemes in Australia, where the Rhipicephalus australis is economically the most damaging bovine ectoparasite [63]. In sheep, few studies were carried out to investigate breed differences to tick infestation. Mirkena et al. [64] reported that local sheep breeds were more resistant in general to stressors such as ticks. Cloete et al. $[65,66]$ argued that the local South African Namaqua Afrikaner fat-tailed breed outperformed the commercial Dorper and South African Mutton Merinos breeds in terms of low tick counts. The heritability of "total tick count" was estimated to be 0.39-0.54 [19] and 0.43-0.44 [66] among Norwegian lambs and South African sheep breeds, respectively. Resistance to ticks is dependent on the tick species, the host and the environment. It could be measured by estimating the reduction in the numbers of ticks, particularly the engorged specimens decrease, the weight of engorged ticks and the duration of blood-feeding besides interruption of tick development [57]. These indicators are suitable to be measured when animals are kept under experimental conditions.

Queue Fine de 1'Ouest ewes were also less susceptible to the infection by piroplasms, but further studies are needed to confirm if this low susceptibility is not due to low tick infestation occurrence or to other factors. Previous descriptive studies carried out in Tunisia support our findings and showed that QFO breed was always less infected than Barbarine breed by several tick-borne pathogens: Babesia ovis, Theileria ovis, Mycoplasma ovis, Anaplasma ovis and Borrelia burgdorferi s.1. [2,4,67,68].

\subsection{Sheep Ticks and Agroecological Variability}

The majority $(646 / 707,91.4 \%)$ of collected ticks during the 8 successive seasons were Rhipicephalus sanguineus s.l., the most widespread tick in the world that colonizes both temperate and tropical regions [69]. Almost two-thirds (75.4\%) of the Rhipicephalus sanguineus ticks were collected from Barbarine ewes, while $24.6 \%$ were collected from QFO ewes. Further studies are needed to confirm resistance to Rhipicephalus sanguineus among QFO sheep in Tunisia. Hyalomma impeltatum and Hyalomma dromedarii were found exclusively in the southeast, they are adapted to the Saharan climate, and they also infest dromedaries (data not shown). Hyalomma spp. ticks are very important vectors since they transmit the Crimean Congo hemorrhagic fever virus (CCHFv) [70]. As sheep play an important role as reservoir of $\mathrm{CCHFv}$ and several other tick-borne viruses, it could be of paramount interest to select tick-resistant sheep breeds to reduce the infection of these animals.

Hyalomma excavatum was mostly found in the southeast, and this is concordant with the findings of Rjeibi et al. [71], who reported that $84.3 \%(118 / 140)$ of this tick species were collected from sheep in the southwest of Tunisia (Kébili district). Since Rjeibi et al. carried out the survey only in QFO sheep breed, no comparison was made with other sheep breeds regarding tick infestation. Hyalomma excavatum was also collected from Barbarine sheep in Sened locality (Gafsa district, Center-west Tunisia), an arid region with the maximum temperature reaching $49^{\circ} \mathrm{C}$ in summer [72].

\subsection{Dynamic of Sheep Ticks under Climate Change Context}

The dynamic activity of Rhipicephalus sanguineus along the 8 successive trimesters was marked by an important peak in summer (July 2019) and the smallest one in spring (April 2018 and 2019). Our results are consistent with the basic knowledge on Rhipicephalus spp. ticks activity, which is found along the year with a peak of activity in spring and summer $[69,73]$. This is also concordant with the findings of Elati [28] and Rjeibi [67], 
in which the highest values of tick infestation prevalence were observed in August and July, respectively. According to Köppen-Geiger classification, the climate in Tunisia is classified as the Mediterranean with hot summer in the northern part, whereas it is classified semiarid in Central Tunisia, hot in center-east and cold in center-west and desert in south [74]. These variabilities in climate patterns from north to south of Tunisia explain the polymorphism of tick parasitism on sheep in different Tunisian regions. Indeed, the average minimum temperatures in January ranged between 2.6 to $6.8^{\circ} \mathrm{C}$ [75] in north Tunisia, and ticks are not found on animals, contrary to south Tunisia, where ticks were present during the same period. All the tick infestation parameters increased during the visits of 2019 and 2020 in comparison to 2018. The observed difference could be explained by the warmest temperatures recorded during 2019. Indeed, the World Meteorological Organization [76] announced that 2019 was the 2 nd warmest year in the last decade, with a $1.5^{\circ} \mathrm{C}$ increase in mean temperature. Based on the calculation of the regional climate change index (RCCI), the Mediterranean region appeared as the primary hotspot, making the Mediterranean countries, including Tunisia, vulnerable and the most prone to climate change [77]. As climate change is incriminated in the increase of several ticks and tick-borne pathogens burdens [78], it is expected that tick distribution will change in Tunisia in the near future.

\section{Conclusions}

The Tunisian Queue Fine de l'Ouest sheep breed appears to present an interesting phenotypic resistance to ticks and piroplasms when compared to the Barbarine breed, even when kept under the same herd's management and environmental conditions. This finding needs more investigations from genetic/genomic, immunologic and behavioral perspectives to fully understand mechanisms of resistance and make concrete control strategies.

Supplementary Materials: The following are available online at https://www.mdpi.com/2076-2 615/11/3/839/s1, Table S1: Prevalence of tick infestation according to studied regions and sheep breeds during 8 sampling rounds.

Author Contributions: Conceptualization, M.R. (Mourad Rekik) and M.G.; data curation, M.K.K. and M.R. (Mariem Rouatbi); formal analysis, M.K.K. and M.R. (Mariem Rouatbi); funding acquisition, A.H. and M.R. (Mourad Rekik); investigation, M.K.K., R.R., L.S. and M.J.; methodology, M.R. (Mourad Rekik) and M.G.; project administration, M.G. and M.R. (Mourad Rekik); supervision, M.G. and M.R. (Mourad Rekik); validation, M.R. (Mourad Rekik) and M.G.; writing—original draft, M.K.K.; writing一review and editing, A.H., M.G. and M.R. (Mourad Rekik). All authors have read and agreed to the published version of the manuscript.

Funding: This research was funded by the Arab Fund for Social and Economic Development and received through the International Center for Agricultural Research in the Dry Areas, under grant number 131,001. This paper was also partly funded by the CGIAR research program on Livestock and the Tunisian Ministry of Higher Education and Scientific Research through the "Laboratoire d'épidémiologie d'infections enzootiques des herbivores, application à la lutte" under the grant number LR16AGR01.

Institutional Review Board Statement: Ethical review and approval were waived for this study, due to the presence of a licensed veterinary surgeon during each visit to the farms and the compliance of all his practices with the recommendations of the National Tunisian Council of Veterinary practitioners (Conseil National de l'Ordre des Médecins Vétérinaires de Tunisie).

Acknowledgments: The authors thank all the veterinarians for their valuable support and all the farmers that participated in the study for 2 years.

Conflicts of Interest: The authors declare no conflict of interest.

\section{References}

1. Rjeibi, M.R.; Darghouth, M.A.; Gharbi, M. Prevalence of Theileria and Babesia species in Tunisian sheep. Onderstepoort J. Vet. Res. 2016, 83, 6. [CrossRef] [PubMed]

2. Rjeibi, M.R.; Darghouth, M.A.; Omri, H.; Souidi, K.; Rekik, M.; Gharbi, M. First molecular isolation of Mycoplasma ovis from small ruminants in North Africa. Onderstepoort J. Vet. Res. 2015, 82, e6. [CrossRef] [PubMed] 
3. Belkahia, H.; Ben Said, M.; El Mabrouk, N.; Saidani, M.; Cherni, C.; Ben Hassen, M.; Bouattour, A.; Messadi, L. Seasonal dynamics, spatial distribution and genetic analysis of Anaplasma species infecting small ruminants from Northern Tunisia. Infect. Genet. Evol. 2017, 54, 66-73. [CrossRef]

4. Ben Said, M.; Belkahia, H.; Alberti, A.; Abdi, K.; Zhioua, M.; Daaloul-Jedidi, M.; Messadi, L. First molecular evidence of Borrelia burgdorferi sensu lato in goats, sheep, cattle and camels in Tunisia. Ann. Agric. Environ. Med. 2016, 23, 442-447. [CrossRef]

5. De La Fuente, J. Overview: Ticks as vectors of pathogens that cause disease in humans and animals. Front. Biosci. 2008, 13, 6938-6946. [CrossRef]

6. Kunz, S.; Kemp, D. Insecticides and acaricides: Resistance and environmental impact. Rev. Sci. Tech. 1994, 13, 1249-1286. [CrossRef]

7. Abbas, R.Z.; Zaman, M.A.; Colwell, D.D.; Gilleard, J.; Iqbal, Z. Acaricide resistance in cattle ticks and approaches to its management: The state of play. Vet. Parasitol. 2014, 203, 6-20. [CrossRef]

8. Shyma, K.P.; Gupta, J.P.; Singh, V. Breeding strategies for tick resistance in tropical cattle: A sustainable approach for tick control. J. Parasit. Dis. 2013, 39, 1-6. [CrossRef]

9. Råberg, L.; Sim, D.; Read, A.F. Disentangling Genetic Variation for Resistance and Tolerance to Infectious Diseases in Animals. Science 2007, 318, 812-814. [CrossRef]

10. Marufu, M.C.; Qokweni, L.; Chimonyo, M.; Dzama, K. Relationships between tick counts and coat characteristics in Nguni and Bonsmara cattle reared on semiarid rangelands in South Africa. Ticks Tick Borne Dis. 2011, 2, 172-177. [CrossRef]

11. De Castro, J.J.; Capstick, P.B.; Nokoe, S.; Kiara, H.; Rinkanya, F.; Slade, R.; Okello, O.; Bennun, L. Towards the selection of cattle for tick resistance in Africa. Exp. Appl. Acarol. 1991, 12, 219-227. [CrossRef]

12. Mansfield, K.L.; Johnson, N.; Phipps, L.P.; Stephenson, J.R.; Fooks, A.R.; Solomon, T. Tick-borne encephalitis virus-A review of an emerging zoonosis. J. Gen. Virol. 2009, 90, 1781-1794. [CrossRef]

13. Rechav, Y.; Magano, S.R.; Fielden, L.J. The effects of tick numbers and intervals between infestations on the resistance acquired by guinea-pigs to adults of Rhipicephalus evertsi evertsi (Acari: Ixodidae). Exp. Appl. Acarol. 1994, 18, 735-745. [CrossRef]

14. Rechav, Y.; Fielden, L.J. The effect of various host species on the feeding performance of immature stages of the tick Hyalomma truncatum (Acari: Ixodidae). Exp. Appl. Acarol. 1997, 21, 551-559. [CrossRef]

15. Robbertse, L.; Richards, S.A.; Maritz-Olivier, C. Bovine Immune Factors Underlying Tick Resistance: Integration and Future Directions. Front. Cell. Infect. Microbiol. 2017, 7, 522. [CrossRef]

16. Mapholi, N.; Maiwashe, A.; Matika, O.; Riggio, V.; Banga, C.; MacNeil, M.; Muchenje, V.; Nephawe, K.; Dzama, K. Genetic parameters for tick counts across months for different tick species and anatomical locations in South African Nguni cattle. Trop. Anim. Health Prod. 2017, 49, 1201-1210. [CrossRef]

17. Scholtz, A.J.; Cloete, S.W.P.; Du Toit, E.; Van Wyk, J.B.; De K van der Linde, T.C. A survey of the prevalence of blowfly strike and the control measures used in the Rûens area of the Western Cape Province of South Africa. J. S. Afr. Vet. Assoc. 2011, 82, 107-115. [CrossRef]

18. Bishop, S.C. Possibilities to breed for resistance to nematode parasite infections in small ruminants in tropical production systems. Animal 2012, 6, 741-747. [CrossRef]

19. Grova, L.; Sae-Lim, P.; Olesen, I. Genetic parameters of tick-infestation on lambs of the Norwegian White Sheep. In Proceedings of the 10th World Congress on Genetics Applied to Livestock Production, Vancouver, BC, Canada, 17-24 August 2014.

20. Budeli, M.; Nephawe, K.; Norris, D.; Selapa, N.; Bergh, L.; Maiwashe, A. Genetic parameter estimates for tick resistance in Bonsmara cattle. S. Afr. J. Anim. Sci. 2010, 39, 321-327. [CrossRef]

21. Maharana, B.; Baithalu, R.; Allaie, I.; Samal, C. Mechanism of Immunity to Tick infestation in Livestock. Vet. World 2011, 4, 131-135. [CrossRef]

22. Wada, T.; Ishiwata, K.; Koseki, H.; Ishikura, T.; Ugajin, T.; Ohnuma, N.; Obata, K.; Ishikawa, R.; Yoshikawa, S.; Mukai, K.; et al. Selective ablation of basophils in mice reveals their non redundant role in acquired immunity against ticks. J. Clin. Investig. 2010, 120, 2867-2875. [CrossRef]

23. Barriga, O.O.; Andujar, F.; Andrzejewski, W.J. Manifestations of Immunity in Sheep Repeatedly Infested with Amblyomma americanum Ticks. J. Parasitol. 1991, 77, 703. [CrossRef]

24. Abdul-Amir, I.; Gray, J. Resistance of sheep to laboratory infestations of the tick, Ixodes ricinus. Res. Vet. Sci. 1987, 43, 266-267. [CrossRef]

25. Boppana, D.K.V.; Dhinakarraj, G.; John, L.; Wikel, S.K.; Latha, B.R.; Gomathinayagam, S. In vivo immunomodulatory effects of ixodid ticks on ovine circulating T- and B-lymphocytes. Parasite Immunol. 2004, 26, 83-93. [CrossRef]

26. Piper, E.K.; Jackson, L.; Bielefeldt-Ohmann, H.; Gondro, C.; Lew-Tabor, A.E.; Jonsson, N.N. Tick-susceptible Bos taurus cattle display an increased cellular response at the site of larval Rhipicephalus (Boophilus) microplus attachment, compared with tickresistant Bos indicus cattle. Int. J. Parasitol. 2010, 40, 431-441. [CrossRef]

27. Marufu, M.C.; Chimonyo, M.; Mans, B.J.; Dzama, K. Cutaneous hypersensitivity responses to Rhipicephalus tick larval antigens in pre-sensitized cattle. Ticks Tick Borne Dis. 2013, 4, 311-316. [CrossRef]

28. Elati, K.; Hamdi, D.; Jdidi, M.; Rekik, M.; Gharbi, M. Differences in tick infestation of Tunisian sheep breeds. Vet. Parasitol. Reg. Stud. Rep. 2018, 13, 50-54. [CrossRef] 
29. Rekik, M.; Aloulou, R.; Ben Hammouda, M. Small Ruminant Breeds of Tunisia. In Characterisation of Small Ruminant Breeds in West Asia and North Africa; Iniguez, L., Ed.; International Center for Agricultural Research in the Dry Areas (ICARDA): Beirut, Lebanon, 2005; pp. 91-140.

30. Bedhiaf-Romdhani, S.; Djemali, M.; Zaklouta, M.; Iñiguez, L. Monitoring crossbreeding trends in native Tunisian sheep breeds. Small Rumin. Res. 2008, 74, 274-278. [CrossRef]

31. Rouabeh, A.; Jemli, M.H. Agricultura in Tunisia; Fondazione de Sardegna: Sardaigne, Italy, 2016; Available online: https: / / slideplayer.fr/slide/12024178/ (accessed on 5 July 2019).

32. Ben Sassi-Zaidy, Y.; Maretto, F.; Charfi-Cheikrouha, F.; Cassandro, M. Genetic diversity, structure, and breed relationships in Tunisian sheep. Small Rumin. Res. 2014, 119, 52-56. [CrossRef]

33. Mason, I.L. Sheep Breeds of the Mediterranean; Bucks, F.R., Ed.; Commonwealth Agricultural Bureaux: Edinburgh, UK, 1967.

34. Djemali, M.; Aloulou, R.; Sassi, M. Adjustment factors and genetic and phenotypic parameters for growth traits of Barbarine lambs in Tunisia. Small Rumin. Res. 1994, 13, 41-47. [CrossRef]

35. Tolone, M.; Mastrangelo, S.; Rosa, A.J.; Portolano, B. Genetic diversity and population structure of Sicilian sheep breeds using microsatellite markers. Small Rumin. Res. 2012, 102, 18-25. [CrossRef]

36. Ben Salem, H.; Lassoued, N.; Rekik, M. Merits of the fat-tailed Barbarine sheep raised in different production systems in Tunisia: Digestive, productive and reproductive characteristics. Trop. Anim. Health Prod. 2011, 43, 1357-1370. [CrossRef] [PubMed]

37. Khaldi, Z.; Rekik, B.; Haddad, B.; Zourgui, L.; Souid, S. Genetic characterization of three ovine breeds in Tunisia using randomly amplified polymorphic DNA markers. Livest. Res. Rural Dev. 2010, 22, 3.

38. Atti, N.; Khaldi, G. Performance of the fat-tailed Barbarine sheep in its environment: Adaptive capacity to alternation of underfeeding and re-feeding periods. A review. Anim. Res. 2004, 53, 165-176. [CrossRef]

39. Bedhiaf-Romdhani, S.; Djemali, M.; Belló, A. Inventaire des différents écotypes de la race Barbarine en Tunisie. Anim. Genet. Resour. Inf. 2008, 43, 41-47. [CrossRef]

40. Sassi-Zaidy, Y.B.; Maretto, F.; Zanetti, E.; Hajji, G.M.; Charfi-Cheikrouha, F.; Cassandro, M. Genetic structure and variability within and among populations of the fat-tailed Barbarine sheep breed using microsatellites markers. Afr. J. Biotechnol. 2014, 13, 44-54. [CrossRef]

41. M'naour, D. Genetic Improvement Objectives of Sheep and Goats in Tunisia. Lessons Learned. In Analysis and Definition of the Objectives in Genetic Improvement Programmes in Sheep and Goats. An Economic Approach to Increase Their Profitability; CIHEAM: Zaragoza, Spain, 2000; Volume 43, pp. 121-127.

42. El Hentati, H. Genetic diversity of two Tunisian sheep breeds using random amplified polymorphic DNA (RAPD) analysis. Afr. J. Biotechnol. 2012, 11, 4109-4115. [CrossRef]

43. Laval, G.; Iannuccelli, N.; Legault, C.; Milan, D.; Groenen, M.A.; Giuffra, E.; Andersson, L.; Nissen, P.H.; Jørgensen, C.B.; Beeckmann, P.; et al. Genetic diversity of eleven European pig breeds. Genet. Sel. Evol. 2000, 32, 187-203. [CrossRef]

44. Kenyon, P.R.; Maloney, S.K.; Blache, D. Review of sheep body condition score in relation to production characteristics. N. Zeal. J. Agric. Res. 2014, 57, 38-64. [CrossRef]

45. Walker, A.R.; Bouattour, A.; Camicas, J.; Estrada-Pena, A.; Horac, I.G.; Latif, A.A.; Pegram, R.G.; Preston, P.M. Ticks of Domestic Animals in Africa: A Guide to Identification of Species; Bioscience Reports: Edinburgh, UK, 2003; ISBN 0-9545173-0-X.

46. Cebra, C.; Cebra, M. Diseases of the Hematologic, Immunologic, and Lymphatic Systems (Multisystem Diseases). In Sheep and Goat Medicine; Pugh, D.G., Braid, A.N., Eds.; Elsevier-Saunders: Philadelphia, PA, USA, 2012; pp. 466-514, ISBN 9781437723533.

47. Wang, Y.; Tian, R.-M.; Gao, Z.M.; Bougouffa, S.; Qian, P.-Y. Optimal Eukaryotic 18S and Universal 16S/18S Ribosomal RNA Primers and Their Application in a Study of Symbiosis. PLoS ONE 2014, 9, e90053. [CrossRef]

48. Gubbels, J.M.; De Vos, A.P.; Van Der Weide, M.; Viseras, J.; Schouls, L.M.; De Vries, E.; Jongejan, F. Simultaneous Detection of Bovine Theileria and Babesia Species by Reverse Line Blot Hybridization. J. Clin. Microbiol. 1999, 37, 1782-1789. [CrossRef] [PubMed]

49. Bush, A.O.; Lafferty, K.D.; Lotz, J.M.; Shostak, A.W. Parasitology Meets Ecology on Its Own Terms: Margolis et al. Revisited. J. Parasitol. 1997, 83, 575-583. [CrossRef] [PubMed]

50. Schwartz, D. Méthodes Statistiques à L'usage des Médecins et des Biologistes, 4th ed.; Flammarion: Paris, France, 1993 ; ISBN 2257103262.

51. Sae-Lim, P.; Grøva, L.; Olesen, I.; Varona, L. A comparison of nonlinear mixed models and response to selection of tick-infestation on lambs. PLoS ONE 2017, 12, e0172711. [CrossRef]

52. Zaibet, L.; Abelhafid, H.; Hammami, S.; Jabbar, M. Efficience du Marché des Petits Ruminants: Rôle de la Santé Animale et Coûts de Transaction. In Sustainability of Small Ruminant Production Systems in Tunisia: A Health Marketing Approach; Zaibet, L., Hammami, S., Jabbar, M., Eds.; International Livestock Research Institute: Nairobi, Kenya, 2009; pp. 41-58.

53. Rouatbi, M.; Amairia, S.; Amdouni, Y.; Boussaadoun, M.A.; Ayadi, O.; Al-Hosary, A.A.T.; Rekik, M.; Ben Abdallah, R.; Aoun, K.; Darghouth, M.A.; et al. Toxoplasma gondii infection and toxoplasmosis in North Africa: A review. Parasite 2019, 26, 6. [CrossRef]

54. Amdouni, Y.; Rouatbi, M.; Lassoued, N.; Rekik, M.; Gharbi, M. Neospora caninum Natural Infection in Tunisian Rams: Serological Study and Molecular Identification of Infection in Semen. Acta Parasitol. 2019, 64, 821-828. [CrossRef]

55. Rouatbi, M.; Gharbi, M.; Rjeibi, M.R.; Ben Salem, I.; Akkari, H.; Lassoued, N.; Rekik, M. Effect of the infection with the nematode Haemonchus contortus (Strongylida: Trichostrongylidae) on the haematological, biochemical, clinical and reproductive traits in rams. Onderstepoort J. Vet. Res. 2016, 83. [CrossRef] [PubMed] 
56. Elati, K.; Aloui, S.; Dhibi, M.; Rekik, M.; Gharbi, M. Seasonal variation of lungworm infestation of ewes at Sidi Bouzid slaughterhouse (Central Tunisia). Rev. Élev. Méd. Vét. Pays Trop. 2018, 70, 137-141. [CrossRef]

57. Rechav, Y. Naturally acquired resistance to ticks-A global view. Int. J. Trop. Insect Sci. 1992, 13, 495-504. [CrossRef]

58. Rechav, Y.; Kostrzewski, M.W.; Els, D.A. Resistance of indigenous African cattle to the tick Amblyomma hebraeum. Exp. Appl. Acarol. 1991, 12, 229-241. [CrossRef]

59. Rechav, Y.; Clarke, F.C.; Dauth, J. Acquisition of immunity in cattle against the blue tick, Boophilus decoloratus. Exp. Appl. Acarol. 1991, 11, 51-56. [CrossRef]

60. Allen, J. Host resistance to ectoparasites. Rev. Sci. Tech. (OIE) 1994, 13, 1287-1303. [CrossRef]

61. Piper, E.K.; Jackson, L.; Bagnall, N.H.; Kongsuwan, K.; Lew, A.E.; Jonsson, N.N.; Tabor, A.E. Gene expression in the skin of Bos taurus and Bos indicus cattle infested with the cattle tick, Rhipicephalus (Boophilus) microplus. Vet. Immunol. Immunopathol. 2008, 126, 110-119. [CrossRef]

62. Piper, E.K.; Jonsson, N.N.; Gondro, C.; Lew-Tabor, A.E.; Moolhuijzen, P.; Vance, M.E.; Jackson, L. Immunological Profiles of Bos taurus and Bos indicus Cattle Infested with the Cattle Tick, Rhipicephalus (Boophilus) microplus. Clin. Vaccine Immunol. 2009, 16, 1074-1086. [CrossRef]

63. Springell, P.H. The Cattle Tick in Relation to Animal Production in Australia; FAO: Rome, Italy, 1983.

64. Mirkena, T.; Duguma, G.; Haile, A.; Tibbo, M.; Okeyo, A.; Wurzinger, M.; Sölkner, J. Genetics of adaptation in domestic farm animals: A review. Livest. Sci. 2010, 132, 1-12. [CrossRef]

65. Cloete, J.J.E.; Cloete, S.W.P.; Scholtz, A.J.; Matthee, S. The effect of breed, ewe age and season on tick counts of indigenous and commercial sheep in South Africa. Proc. Assoc. Adv. Anim. Breed. Genet. 2013, 20, 187-190.

66. Cloete, S.; Cloete, J.; Scholtz, A. Genetic parameters for tick count and udder health in commercial and indigenous ewes in South Africa. Vet. Parasitol. 2016, 230, 33-42. [CrossRef]

67. Rjeibi, M.R.; Gharbi, M.; Mhadhbi, M.; Mabrouk, W.; Ayari, B.; Nasfi, I.; Jedidi, M.; Sassi, L.; Rekik, M.; Darghouth, M.A. Prevalence of piroplasms in small ruminants in North-West Tunisia and the first genetic characterisation of Babesia ovis in Africa. Parasite 2014, 21, 23. [CrossRef]

68. Ben Said, M.; Belkahia, H.; Alberti, A.; Zobba, R.; Bousrih, M.; Yahiaoui, M.; Daaloul-Jedidi, M.; Mamlouk, A.; Gharbi, M.; Messadi, L. Molecular Survey of Anaplasma Species in Small Ruminants Reveals the Presence of Novel Strains Closely Related to A. phagocytophilumin Tunisia. Vector Borne Zoonotic Dis. 2015, 15, 580-590. [CrossRef]

69. Dantas-Torres, F. Biology and ecology of the brown dog tick, Rhipicephalus sanguineus. Parasites Vectors 2010, 3, 26. [CrossRef]

70. Papa, A.; Tsergouli, K.; Tsioka, K.; Mirazimi, A. Crimean-Congo Haemorrhagic Fever: Tick-Host-Virus Interactions. Front. Cell. Infect. Microbiol. 2017, 7, 213. [CrossRef]

71. Rjeibi, M.R.; Darghouth, M.A.; Rekik, M.; Amor, B.; Sassi, L.; Gharbi, M. First Molecular Identification and Genetic Characterization of Theileria lestoquardi in Sheep of the Maghreb Region. Transbound. Emerg. Dis. 2016, 63, 278-284. [CrossRef]

72. Elati, K.; Ayadi, A.A.; Khbou, M.K.; Jdidi, M.; Rekik, M.; Gharbi, M. Dynamique des populations de tiques infestant les ovins dans les steppes arides de Tunisie. Rev. Élev. Méd. Vét. Pays Trop. 2018, 71, 131. [CrossRef]

73. Estrada-Peña, A.; Bouattour, A.; Camicas, J.L.; Walker, A.R. Ticks of Domestic Animals in the Mediterranean Region. A Guide to Identification of Species; University of Zaragoza: Zaragoza, Spain, 2004; ISBN 9788496214187.

74. Rubel, F.; Kottek, M. Observed and projected climate shifts 1901-2100 depicted by world maps of the Köppen-Geiger climate classification. Meteorol. Z. 2010, 19, 135-141. [CrossRef]

75. Organization Climate Data. Climate Tunisia. Available online: https://fr.climate-data.org/afrique/tunisie/tunis-414/ (accessed on 10 April 2020).

76. World Meteorological Organization. WMO Provisional Statement on the Status of the Global Climate in 2019; WMO: Geneva, Switzerland, 2019.

77. Giorgi, F. Climate change hot-spots. Geophys. Res. Lett. 2006, 33, 1-4. [CrossRef]

78. Bouchard, C.; Dibernardo, A.; Koffi, J.; Wood, H.; Leighton, P.; Lindsay, L.R. Increased risk of tick-borne diseases with climate and environmental changes. Can. Commun. Dis. Rep. 2019, 45, 83-89. [CrossRef] 